\title{
The perlocutionary is political: Listening as self-determination in a Papua New Guinean polity
}

\author{
J A M E S S L O T T A \\ Department of Anthropology, University of California, San Diego 9500 Gilman \\ Drive, MC 0532, La Jolla, CA 92093-0532, USA \\ jslotta@ucsd.edu
}

A B S T R A C T

\begin{abstract}
J. L. Austin's influential dissection of speech acts into locutionary, illocutionary, and perlocutionary acts has given rise to much scholarly attention to illocutionary acts and forces. While the perlocutionary facet of speech acts has gone largely undiscussed by philosophers and linguists, folk theories of language often attend closely to the relation between speech and its consequences. In this article, I discuss one conception of perlocutions prominent in Yopno speaking communities in Papua New Guinea that emphasizes the agentive role of listeners in mediating between speech and its outcome. This cultural conception of perlocutions, I argue, is tied to a political sensibility that stresses the self-determination and equality of adult men. The article shows how cultural conceptions of perlocutions provide insight into political values and practices, and how political concerns inform folk models of perlocutions. (Perlocutions, politics, fashions of speaking, language ideology, Melanesia, Papua New Guinea)*
\end{abstract}

\section{N T R O D U C T I O N}

In one of my first conversations in the Yopno Valley of Papua New Guinea, a young man recounted a conversation he had had with the head of an American-based conservation NGO. He told me that he had expressed to her his desire to see the United States and he seemed confident that, as a result of this expression of interest, she would find a way for him to travel to the American zoo where the NGO was based.

Having myself been the recipient—or rather, the recipient-manqué - of a number of well disguised requests along these lines during my time in Papua New Guinea, I offered the young man a bit of advice: he should speak more directly to the NGO workers, asking explicitly how he could get involved in the conservation work and possibly even travel to the United States someday. In response, he simply pointed out that the NGO director is human and is capable of understanding (Tok Pisin: em man ya, em i gat save 'she's a person, she can understand').

With his pithy rejoinder, he summed up a perspective on agency, communication, and its efficacy that I explore in more detail here. In short, in this view 
recipients of messages are agentive actors in communicative encounters, construing the meaning and force of speech and playing an important role in determining the outcome of speech events. From this perspective, it was not this young man's responsibility to 'speak up', as I suggested that he do; it was his addressee's responsibility to 'listen up' and it was up to her to determine the outcome of this encounter.

This article is concerned, then, with a cultural conception of what J. L. Austin (1962) termed perlocutions. My contention here is that this listener- or recipientcentered view of perlocutions is linked to values and practices central to Yopno village politics. In Austin's influential dissection of speech acts into locutionary, illocutionary, and perlocutionary acts, the perlocutionary facet of speech acts concerns speech as an activity that gives rise to consequences. This contrasts with speech considered as propositionally meaningful (a locutionary act) or as a means of performing conventional social acts (an illocutionary act). ${ }^{1}$ While the illocutionary facet of speech acts has been the subject of extensive theorization, speech act theorists have devoted little attention to the perlocutionary-an unruly, highly contingent domain that is not susceptible to analysis through the use of intuition and considerably decontextualized examples. ${ }^{2}$ When receiving a simple greeting can give rise to joy, wariness, disgust, and seemingly anything else, it proves challenging to isolate necessary or conventional connections between a bit of speech and the effects it brings about.

While speech act theorists have largely disregarded perlocutions, there is no lack of folk theorizing about the ways in which speech affects others. We need only look in the self-help aisle of the local bookstore to find theories of How to win friends and influence people, of how Power questions will allow readers to Build relationships, win new business, influence others, and so on. As with communicative ideologies more generally, such perlocutionary models are about more than just language (Schieffelin, Woolard, \& Kroskrity 1998; Kroskrity 2000b). This is nowhere more evident than in the long history of discussions of 'rhetoric', a prime locus of theorizing 'persuasion' and perlocutions more generally in the European philosophical tradition, and one that is interwoven with cultural views of morality, politics, religion, and human nature (Shuger 1988; Gustafson 1992; Skinner 1996; Fontana, Nederman, \& Remer 2004; Konstan 2006; Garsten 2009). Liberal concerns about self-determination, freedom, rationality, and self-authorizing judgment suffuse the early modern revolt against rhetoric, echoing in Immanuel Kant's view that rhetoric 'insofar as by that is understood the art of persuasion, i.e. of deceiving by means of beautiful illusion... is a dialectic, which borrows from the art of poetry only as much as is necessary to win minds over to the advantage of the speaker before they can judge and to rob them of their freedom' (2000:204). Kant moves seamlessly from an account of how rhetorical speech ('beautiful illusions') affects its audience ('deceiving' and 'winning minds over to the advantage of the speaker before they can judge') to ethical and political concerns about the use of rhetoric to influence persons understood to have the capacity for rational judgment and, therefore, the right and obligation to judge for themselves. In other words, 
persuasion is viewed here through the prism of a liberal political ethics, in which winning over minds before they can judge is an illegitimate perlocutionary act that robs people of their freedom. ${ }^{3}$

It is the contention of this article that cultural conceptions of perlocutions provide a rich source of insight into matters of morality, politics, and personhood, and, in turn, folk models of perlocutions are inflected by their cultural and political milieu. Much as Rosaldo's discussion of illocutionary acts among the Ilongot showed that 'ways of thinking about language and about human agency and personhood are intimately linked' (1982:203), I argue here that conceptions of perlocutions prominent in the Yopno Valley are linked to political values and practices that stress the willfulness, self-determination, and equality of Yopno village residents. I detail a conception of perlocutions in which hearers, or communicative recipients as I term them here, play a key role in mediating between speech and its consequences. In this recipient-centered model of linguistic efficacy, communicative recipients are understood as agentive actors, not merely passive recipients of messages; their agentive 'work' on the speech of others is viewed as the fulcrum between speech and its outcome. This conception of recipient agency and recipients' role in mediating between speech and its consequences is, I show, interwoven with political concerns about equality and self-determination, and ritual practices that work to constitute the Yopno village as a polity composed of willful, self-determining people.

As with other cultural conceptions of perlocutions-for instance, Islamic 'rhetoric' and its emphasis on ethical practices of listening (Hirschkind 2006) or Aristotle's division of rhetoric into three species (deliberative, judicial, and demonstrative) according to the three classes of hearers (Kennedy 2006) - the one I discuss here attends closely to the role of recipients in communicative events. Careful analyses of their role in communicative interactions has provided a salutary reminder that recipients play a significant role in communication. ${ }^{4}$ But Yopno conceptions of the 'work' of recipients in communicative events is not presented here as a corrective to speaker-centered models of meaning and communicative action. Rather, I am interested in how the role of communicative recipients is inflected by political values and practices, giving rise to variation in what it is hearers/recipients are seen to do and expected to do in different speech communities (Philips 1976; Brenneis 1987; see also Kapchan 2008 on musical audition) as well as variation among different types of listening/receiving in a single speech community (Marsilli-Vargas 2014).

The pivotal role of recipients in communicative events is a recurring theme in ethnographies of communication in Oceania. For people in Gapun, Don Kulick has discussed the responsibility and power vested in the receiver of messages to construe their meaning and force, 'the village understanding that the discovery and comprehension of the meaning of speech is the responsibility of the listener' (1992:135). For the Urapmin, 'listeners are responsible for creating the meaning of what they hear', leaving speakers to 'run-it-up-the-flagpole-and-see-whosalutes' (Robbins 2001:906). Duranti has drawn on his research in Samoa (1992) 
to show how the more relational and recipient-oriented ethnotheories of communication found there challenge the focus on speakers and their intentions in a number of influential Western models of meaning and speech acts. In the Yopno Valley itself, Jürg Wassmann reports that to 'listen attentively to others and thereby become "knowing human beings"" is a valued personal trait (1994:655).

Drawing on eighteen months of linguistic and ethnographic research in the Yopno Valley, I elaborate here on what it means to 'listen attentively' by looking at the way speech is talked about in the course of everyday language use, and especially the perlocutionary expressions people use to discuss speech and its consequences in the course of what may be termed political events. I focus on several common ways of talking about speech-'fashions of speaking' about speech, to use Benjamin Lee Whorf's expression (1956) - that impute agency to the recipient in communicative events to affect the outcome of speech events. These fashions of speaking provide one source of evidence for - and serve as one semiotic locus of the cultural conception of perlocutions I discuss here.

A second locus I discuss is an institutionalized ritual of village politics, 'discussions' (Yopno: yay nanda-) among community members in which they collaboratively make decisions about collective projects and concerns. As an activity in which communication itself is a focal point of concern, discussion is a highly visible, public ritual, in which participants act as agentive recipients of each others' talk, standing between each other's talk and the concerted action of the community. Moreover, discussion is a site where the political valences of the perlocutionary become apparent. In discussion, participants demonstrate their selfdetermination and equality by acting as agentive recipients in the process of forging a common will.

A YOPNO PERLOCUTIONARY EXPRESSION

AND ITS ENGLISH COUNTERPARTS IN SPEECH AC T THEORY

Located in the Finisterre Mountains on the border of Morobe and Madang provinces, the Yopno Valley is home to some 8,000 people living in twenty-five villages. Most people in the valley speak Yopno, a Papuan language, and most men and many women under sixty are also able to speak Tok Pisin, an Englishbased creole used in much of Papua New Guinea and a language of schooling in the Yopno Valley since the 1970s. Most everyone in the valley is a subsistence horticulturalist, supplying their own food, shelter, and firewood from land they own as members of a clan.

Almost every village in the valley is composed of multiple clans-generally, four or more - and ownership of the land around a village is divided among them. Prior to pacification by the Australian colonial administration and the Lutheran mission, people did not live in concentrated villages, but built their houses in small clusters on their clan land (Wassmann 1993), gathering together for the purpose of 
warfare and education. Historically, each village was home to several men's houses, in which young men were prepared for adulthood and which served as hubs for religious activities. Warfare between villages is said to have been a particularly potent institution that unified villagers in a common cause.

Following pacification and the end of the men's house regime, Lutheran churches, government and church schools, and ceremonial events have become the prime collective concerns of those who live together in a village. In November of 2008 the village of Nian was preparing to host a large celebration in honor of the tenth anniversary of the construction of a Lutheran church in their village, one built with sawn timber, tin roofing, and concrete that community members had carried up from the seacoast to Nian (elevation 7,000 feet). In the months leading up to the celebration, members of the community worked to gather the food, firewood, and other items necessary to host visitors from throughout the Valley and from urban areas of Papua New Guinea. As the day of the celebration approached, the organizing committee found that they did not have the pigs needed as gifts for guests invited from other villages. A number of the church's pigs had been borrowed by community members and either not repaid or repaid with pigs too young to be used as gifts. Emergency meetings were called and the leading men of the community gathered to figure out how the pigs would be procured. If the visitors came and provided entertainment, support, and gifts, and Nian could not offer them hospitality and gifts in return, this would be a tremendous embarrassment. Much of the discussion in these meetings centered on how to convince community members to donate their pigs for use in the upcoming celebration. Numerous speakers offered ideas, including a church leader, who suggested that they explain to community members that giving pigs as offerings for church events is a way to secure blessings for themselves.

\section{(1) Translated from Yopno ${ }^{5}$}

In the meeting and outside as well we should mention [that giving pigs for the celebration is a way to secure blessings] to those friends who have these kinds of problems. Let's go speak out about it to them.

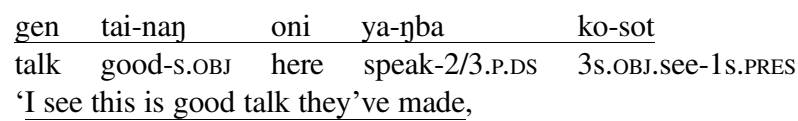

so it would be good that I do this [i.e. give pigs]. Afterwards my life will improve.'

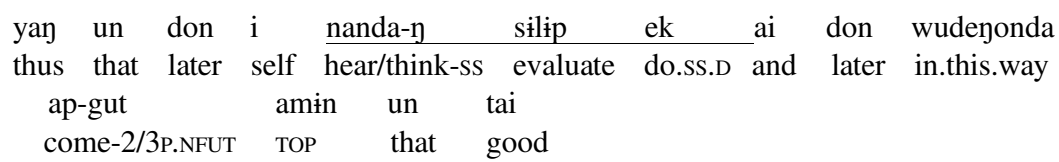

They themselves will evaluate it like that and they will come [bringing pigs] in that way. That would be good. 
This stretch of speech contains a perlocutionary expression commonly heard in meetings of this sort, where the leading men of the community strategize about how to influence others in the community. In the prospective communicative event depicted here, both a speech event ('we should mention [that giving pigs is a way to secure blessings]') and its perlocutionary effect ('they will come [bringing pigs]') are discussed. Interposed between speech and its effect is an act of reception in which the recipient of the leaders' proposed speech 'evaluates' that speech (nanday silip $a$ - 'hearing/thinking and sorting out, evaluating'; this expression along with others is discussed in more detail in the next section). The recipient judges that 'this is good talk' before the desired outcome (i.e. bringing pigs) is reached. In this perlocutionary expression, an act of reception in which the recipient evaluates what they have heard stands between the locutionary act and the perlocutionary outcome.

This Yopno perlocutionary expression differs subtly, but significantly, from the perlocutionary expressions of English that Austin and others have considered in their discussions of speech acts. To summarize briefly, Austin (1962) distinguishes three acts that occur together in a speech event. The locutionary act, 'roughly equivalent to uttering a certain sentence with a certain sense and reference' (1962:108), concerns the representational capacity of speech and its use to refer to things and predicate attributes of them. In contrast, the illocutionary act encompasses the conventional social activities performed in the act of speaking (other than referring and predicating). The perlocutionary act covers speech as an activity that gives rise to effects. By saying 'Don't climb in the washing machine', I am referring to and predicating about 'washing machines' and your relationship to them (a locutionary act); I may be 'warning' you about or 'prohibiting' you from having such relations with the referred-to washing machine (an illocutionary act); and at the same time, by means of this speech, I may get you to stay out of the washing machine, I may upset you, I may make you lose all respect for me, and so on (a perlocutionary act).

Each of these three acts identified by Austin has a set of English verbs and expressions associated with it. Austin provides his own illustrative examples, showing how the same speech event can be reported in English in ways that highlight variously the locutionary, illocutionary, or perlocutionary facet of the speech act. For instance, a speech event in which a man says 'Shoot her!' can be reported variously as follows (from Austin 1962:101-102):

$\begin{array}{ll}\text { Locutionary } & \text { He said to me, 'Shoot her!' } \\ \text { Illocutionary } & \text { He urged me to shoot her. } \\ \text { Perlocutionary } & \text { He persuaded me to shoot her. }\end{array}$

The perlocutionary verbs identified by Austin—persuade, convince, deter - share a common grammatical property that differentiates them from the illocutionary and locutionary verbs he discusses: they are lexical causative verbs, evident in the way they are periphrastically defined (e.g. from The New Oxford American 
Dictionary, Second Edition: persuade, (i) cause (someone) to do something through reasoning or argument, (ii) cause (someone) to believe something; see also Katz 1977:163-66). A number of distributional similarities between perlocutionary verbs and analytic causatives in English also distinguish them from the locutionary and illocutionary verbs Austin discusses. ${ }^{6}$ Persuade along with Austin's other perlocutionary verbs are lexical causative verbs that take human direct objects and for which speech is a stereotypical means of causation.

Austin identifies the perlocutionary act using not only this set of English perlocutionary verbs, but also a periphrastic construction that contains all of the same essential elements. A variety of causative verbs can indicate the effects of a speech act when an adverb of means containing a verb of speaking is included in the sentence (specifically, one whose subject is co-referential with the subject of the causative):

By saying it, I convinced him, or surprised him, or got him to stop. (Austin 1962:109)

In the relevant respects, this periphrastic construction contains all of the elements of a perlocutionary verb like persuade (i.e. a causative whose stereotypical means of causation is speech).

As Michael Silverstein has argued (1979:208-16), Austin's identification of perlocutionary acts as a component of speech events is rooted in the grammatical distinctions and possibilities found in descriptions of speech events in English. English happens to contain causative lexemes and constructions that characterize speech as a cause that brings about effects of various sorts. In contrast, the Yopno perlocutionary expression introduced above encodes a very different relationship between speech and the consequences that it gives rise to. Causation, an important element of the English fashion of speaking, is not present. Further, in the perlocutionary expressions considered by Austin the communicative recipientappearing as the direct object of a (lexical) causative ('I persuaded him to leave') is depicted as a party affected by speech, a causee; the perlocutionary act, according to John Searle, concerns 'the consequences or effects such acts have on the actions, thoughts, beliefs, etc. of hearers' (1969:25). In the Yopno expression I am considering here, the hearer appears as the subject of a verb, and as I discuss further in the next section, they are depicted as an agentive actor in the communicative encounter, not a causee.

When viewed in contrast to other ways of talking about speech and its consequences, Austin's perlocutionary verbs and expressions appear to be what Whorf termed a 'fashion of speaking': 'ways of analyzing and reporting experience which have become fixed in the language... and which cut across the typical grammatical classifications, so that such a 'fashion' may include lexical, morphological, syntactic and otherwise systemically diverse means' (1956:158). Fashions of speaking are language particular 'ways of putting things', combining lexical and grammatical elements in a way that reflects not reality itself, but a linguistically mediated perspective on reality. To take a simple example, the expression 'nature 
abhors a vacuum' is a fashion of speaking, a way of putting things that attributes certain characteristics to nature: as the subject of the verb abhor, nature is presented as something that is sentient (cf. Whorf 1956:222). In the words of Robert Boyle, proponent of the mechanical philosophy that opposed such a view of nature, this was 'looking on things merely corporeal, and oftentimes inanimate things, as if they were endowed with life, sense, and understanding' (quoted in Shapin 1996:151). The conception of nature implicit in the fashion of speaking about nature is rendered explicitly in Boyle's commentary.

In much the same way, Austin's perlocutionary act is an explicit rendering of fashions of speaking about speech in English that lexically and morphosyntactically join causation with speech: speech is depicted as a means of bringing about effects. In Whorfian fashion, the categories latent in this fashion of speaking serve as a guide to the reality of speech acts in Austin's account (see Whorf 1956:80-81). Austin makes explicit, provides a label for, and projects onto reality the covert grammatical and semantic categories of English present in a fashion of speaking about speech.

The Yopno expression, considered as a fashion of speaking, joins rather different elements: the communicative recipient is depicted as an agentive actor whose evaluation of speech stands between talk and its outcome. In a strict sense, then, the Yopno perlocutionary expression discussed here does not fit Austin's Englishbased model of perlocutions. But the contrast of Austin's perlocutionary expressions and the Yopno one points to the fact that there is more than one way to talk about the relation of speech to its consequences. In recognizing the Englishbased parochialism of Austin's account of perlocutions, we open the way to linguistic and ethnographic investigation of other fashions of speaking about speech and its consequences, other metalanguages about communication that emphasize alternative perspectives on the perlocutionary. ${ }^{7}$ As I discuss further in the next section, a number of prominent, commonly used Yopno fashions of speaking about speech bespeak a recipient-centered model of linguistic efficacy, in which not only speech itself, but recipients' uptake of speech is seen to play a pivotal role in shaping the outcome of speech acts.

\section{FASHIONS OF SPEAKING ABOUT \\ COMMUNICATIVE RECIPIENTS IN YOPNO}

Yopno fashions of speaking that frame communicative recipients as agentive actors turn up frequently and prominently in Yopno political discourse. The harangues of community leaders trying to motivate community members to act, the frequent discussions among community members about collective affairs, the criticisms people level at each other for failing to participate in community life - all of these varieties of political discourse are peppered with ways of talking about speech that emphasize the agency of recipients. Before turning to the use of these expressions in the practice of Yopno village politics, I look more closely here at the way these ways of 
talking about talk depict acts of reception in communicative encounters. Routine fashions of speaking about speech such as those discussed here are a semiotic 'site' of language ideologies (Silverstein 1998; Kroskrity 2000a; Philips 2000) that provide a valuable source of insight into cultural understandings of language and communication. In other words, they manifest cultural conceptions of what language is and how communication works in a perceptible form embedded in social life.

Compared to the extensive inventory of metalinguistic verbs in Englishlocutionary, illocutionary, and perlocutionary - the set of metalinguistic verbs in Yopno appears somewhat scanty (a feature of other Papuan languages as well, e.g. Goldman 1983; Merlan \& Rumsey 1991). The most commonly used is an ambitransitive verb of speaking, which also serves as the verb that describes the crow of the rooster, the ringing of a bell, and the sounding of thunder: $y a$ - 'sound, utter, say, speak, vocalize'.

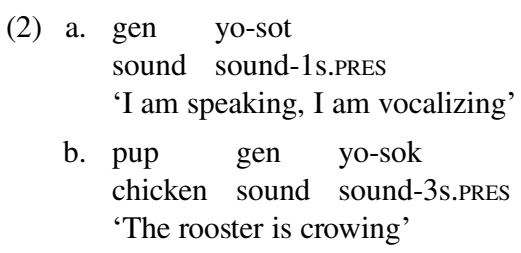

'Generic verbs' with a wide semantic range such as $y a$ - are common in Papuan languages (Pawley 1993,1994; see also Foley 1986:Ch. 5). Their meaning is made more specific through a variety of means, including (i) the use of serial verb constructions, in which multiple verbs combine to form an expression with a more specific meaning, and (ii) the use of nominal complements and adjuncts, such as gen 'vocalization, sound, talk, mouth' in (2) above. ${ }^{8}$ Though gen is itself a fairly generic noun of speaking — or better, a generic noun of sounding - there are nouns with a more specific meaning that may be substituted for it.
(3) gen yo-sot
'I speak, I vocalize'
kap yo-sot
'I sing'
bisit yo-sot
'I pray, I appeal for'

These nouns occur as arguments of a variety of types of verbs, the combination of a noun of speaking with different verbs furnishing a rich source of metalinguistic expressions.

The fashions of speaking about speech that I focus on here all include a noun of speaking or other metalinguistic expression occurring as the object of a number of verbs, none of which are specifically associated with the domain of speech. ${ }^{9}$ Example (4) is one way that the failure to heed instructions, advice, and other talk is discussed. 

(4) yay idin da-i-n-i pi-ki pa-ga jipgwan thus here 2P.OBJ-tell-2/3P.NPAST-TOP down-go.ss P.OBJ-go.ss where

$$
\begin{array}{ll}
\text { yo-pm-ek } & \text { ekw-ay } \\
\text { 3P.oBJ-put-sS.D } & \text { be-2/3P.PRES }
\end{array}
$$
'What they told you, you took them and left them where?'

In this way of talking about the failure to heed speech, talk ('what they told you') is spoken of as something 'taken' and 'left' somewhere, in the same way one talks about moving and placing a physical object. The 'logic' behind what may appear to be a 'highly idiomatic' fashion of speaking (Whorf 1956:222), though, becomes clearer when we set it next to other ways in which speech is said to be handled by recipients. In contrast to speech being left somewhere, speech may be 'held onto, kept' (abida-).
(5) gen tim yi-pma-k-nay pakyan-si abido-ni talk portion 3s.OBJ-put-3s.NPAST-S.OBJ carefully-EMPH hold-2/3P.FuT 'you all hold on well to the talk he presented'

To 'hold onto' speech is to bear it in mind and act in accordance with it. These are two fashions of speaking that coalesce around the sense that people 'handle' and 'retain' speech, which can influence their thoughts and actions only if it is handled properly. In much the same way, talk may be 'protected, looked after' (kutna-), like a prize possession or a person in one's care, as shown in (6).

(6)

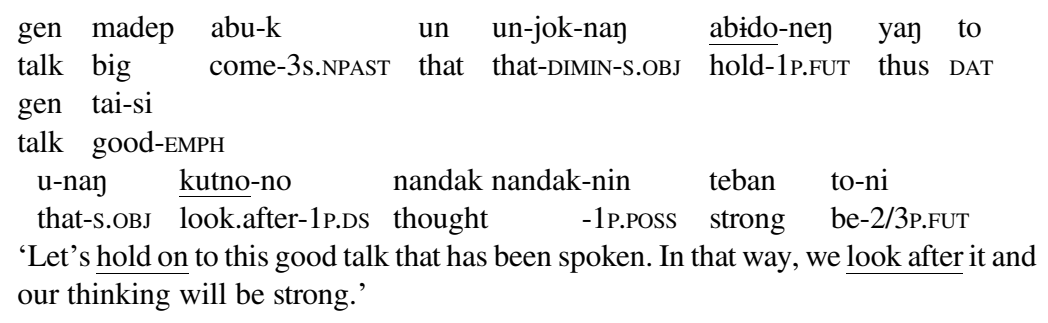

In these three related fashions of speaking, talk is something that the recipient maintains in proximity to themselves or not. Further, the recipient is represented as a relatively agentive actor in the communicative event - one who is a willful, controlling, and instigating participant (Van Valin 2005). That these expressions impute agency to the actor can be seen, for one, in the fact that they can be and often are used in directives, occurring with second person subjects and near future-imperative inflection (gen taisi abida! 'Hold on to this good talk!'). In contrast to predicates with relatively agentive subject arguments, predicates with nonagentive subject arguments sound strange when used in a directive: kawmi nanda! 'Feel cold!', which is awkward in English as well. The awkwardness of this expression 
arises from the contradictory attributes it imputes to the subject argument. While a directive presupposes that the second person subject argument has a degree of volition and control in instigating an activity, the predicate-argument combination kawmi nanda- presupposes that the subject argument is not a willful, controlling instigator of this state. The common use of predicate-argument combinations such as 'hold on to talk' in directives, in contrast, indicates that the fashions of speaking I discuss here do impute a degree of agency to their subject argument, the recipient of talk. Additionally, the fashions of speaking I have been discussing may and occasionally do include the adverb of manner pakyay 'carefully', indicating that the activity described is one that the subject argument is capable of controlling. This adverb does not occur with a verb like kimak- 'die' (*pakyaygok kimakgit 'he died carefully'), in which control is not a property imputed to the subject argument. ${ }^{10}$

The representation of recipients as agentive actors in communicative events is found in a variety of other fashions of speaking as well. These include a set of ways of talking about the evaluation of speech, which will be important in the discussion in the next section. Talk is spoken of as something that is 'broken up, split' ( puda-) by the recipient, as in (7).

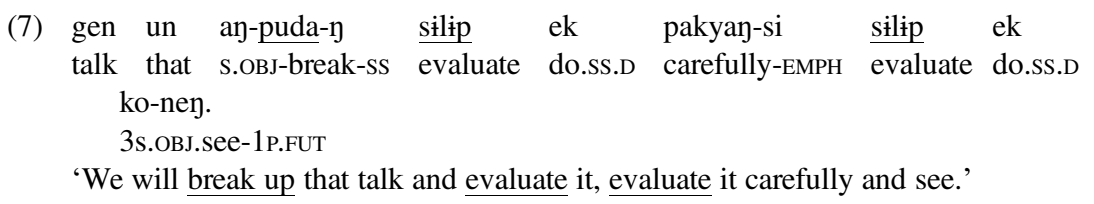

In the same way one speaks of breaking up firewood, talk can be split. The logic behind this way of putting things can be clarified by noting the common use of the verb phrase silip $a$ - 'group, sort, distribute, organize' in collocation with puda-. Siltip $a$ - on its own can be used to describe how a woman distributes food from a pot to individual plates, how a person arranges vendibles at market, or how items are organized and distributed at an exchange ceremony. When I asked people about the meaning of the expression gen siltip $a$ - 'sort out, weigh, evaluate talk', they would often say something like: "you sort out talk, this part of the talk is good, this isn't" or "this part is true, this isn't". This explanation was often accompanied by gestures that mimicked distributing food from a pot onto plates - taking talk from the pot and putting it on one plate ('good talk') and then taking other talk and putting it on another plate ('bad talk').

'Breaking up' talk then is the first step in 'sorting out' talk. And 'sorting out' talk is an all purpose way of talking about evaluating talk-determining what is good and bad, true and false, in it — but also what its hidden meanings and implications are (see (1) for another use of this verb phrase, there in a serial verb construction with nanda- 'to hear, to think'). Similarly, the roughly synonymous verb phrase kokwin a- 'evaluate, sort, distribute' is also used as a way of talking about the work of recipients in examining and evaluating talk, as shown in (8). 


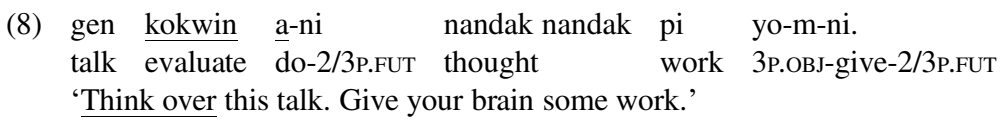

In these related fashions of speaking, the recipient works over the talk of someone else, 'breaking it up' and 'sorting it out' to determine what is being said and whether that talk is good or bad, true or false.

All of these ways of talking about talk taken together present the recipient in a communicative event as relatively agentive, handling the talk of others in a variety of ways. Related to them are a number of ways of talking about the act of speaking itself. Verbs like - pma- 'leave, put, place' and ikak- 'push, move' combined with a noun of speaking are used to characterize the sending of messages.

(9) a. -pma- 'leave, put, place'

gen asi-nan yi-pma-k to taiyangok un abid-ek
talk true-s.oBj 3s.obj-put-3s.NPAST so well that hold-ss.D
'This is important talk he has presented so hold onto it well.'

b. tkak- 'push, move'

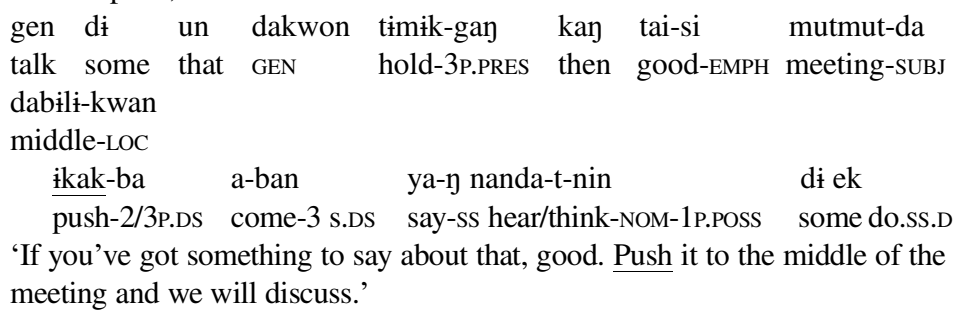

The use of 'push, move' or 'leave, put' to describe the act of speaking further emphasizes the work of recipients in communicative events. Talk, in these cases, is portrayed as something moved into the vicinity of the recipient ('pushed' or 'left' there), leaving it up to recipients to pick it up: examine it, hold onto it, discuss it or not. In effect, these fashions of speaking detailed here depict communication as a variety of 'offering up' or 'making available' talk, in which the recipient is left to agentively 'take' the object, as in Robbins' characterization of the Urapmin 'run-it-up-the-flagpole-and-see-who-salutes' view of communication (2001:906).

I do not mean to imply through my presentation of several common Yopno fashions of speaking about speech that these are the only ways of talking about talk in common use in Yopno communities or that they indicate a single, coherent, and shared ideology of communication held by all. ${ }^{11}$ As much recent research on language ideologies has stressed, tension and contestation among multiple ideologies of communication in a speech community is common (Briggs 1992; Schieffelin, Woolard, \& Kroskrity 1998:Part 3). It is imperative, then, to locate ideologies in 
the institutions and practices where they are anchored in social life. In the next section, I situate these fashions of speaking in some of the discursive arenas where they are commonly used, paying particular attention to their use in political discourse. Contextualizing these fashions of speaking will provide a lens on how a conception of recipients as agentive actors is bound up with perlocutions and politics.

Among the varieties of political discourse I touch on, I focus on a ritualized communicative practice termed discussion (yay nanda- 'talking hearing/thinking'). Not only is discussion a site where fashions of speaking about agentive recipients are commonly found, discussion is itself a ritualized practice that emphasizes the agency of recipients. ${ }^{12}$ In discussion, the self-determination and equality of people in a Yopno village are exhibited in their agentive reception of the speech of others and in their respect for others' agentive reception of their own speech. Discussion then is a second site — one of ritualized practice (Kroskrity 1998)—where an ideology of recipient agency materializes in social life.

As Whorf noted, fashions of speaking 'grow up' together with cultural norms and practices, 'constantly influencing each other' (1956:156). In discussion, we find an interesting locus of this dialectic, where communicative practice and fashions of speaking about communicative practice mirror one another, mutually reinforcing each other. How people talk about talk-their metadiscourses about talk-as well as the way they talk-their communicative practice-materialize a common ideology of perlocutions in which recipients' handling of speech stands between speech and its outcome. In turning to the domain of communicative practice, we see how multiple sites of ideology, including both fashions of speaking and communicative rituals, operate in tandem to reinforce an ideology of communication. More than that, we situate this ideology in the practice of Yopno village politics, where we can more clearly see how the perlocutionary is political.

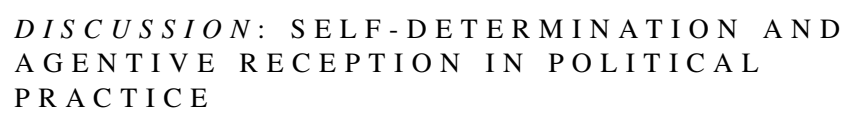

Yopno villages are fragile polities (see Stasch 2009 and Handman 2015 for discussion of the fragility of villages elsewhere in Melanesia). Given the degree to which families and clans are economically self-sufficient and the degree to which people — and adult men especially — prize their equality and self-determination, it requires constant effort to bring people together to participate in the collective activities of the community. Though people value schools, churches, ceremonial events, and other products of the concerted efforts of villages, they often are said to follow their own desires rather than think of their community. When dissatisfied or disinterested with life in a village, people go to live with relations in other villages or retreat to their forest houses, where they can live on their own land far from others. Or, they simply ignore community affairs and tend to their own. 
Though every village has people who are recognized as community leadersthe heads of clans, school board members, and people who hold positions in the Lutheran Church - these people, almost all men, have relatively little power over community members. Read's (1959:431) description of the Gahuku-Gama applies well to political relations in Yopno villages: 'No individual commands instrumentalities which might enable him to dictate the course of action which a gathering must follow'. My first months in the field, I routinely followed the publicly announced instructions of community leaders, appearing at the school for cleaning and maintenance work, attending church gatherings, and showing up for community meetings to find only a small portion of community assembled. After several hours, when it became clear that most of the community was not going to show up, we would disband and more announcements would follow the next day in an effort to ensure that the community en masse would participate next time.

Projects and activities announced by leaders are often met with complaints from community members that they have not been consulted, that leaders were treating them like their 'laborers' (oman amin) or, in the Biblical idiom, their 'slaves' (slev). When a person feels they have not been included in the decision-making process or they are dissatisfied with a plan of action announced by community leaders, they simply do not participate.

Decision-making in Yopno villages, where community leaders cannot simply dictate a course of action to others, often takes the form of discussion. Most weeks at least one discussion takes place in a Yopno village involving some portion of the community, each discussion part of an often long series. On most matters of public import, a select group of men gather to discuss what is to be done and how to go about doing it. They set an agenda and strategize about how to influence others to follow the route they have decided on. After this, they hold large public meetings, which are open to all of the men and women of the community and which follow the agenda and strategies set out in the earlier closed meeting. These meetings are often followed by smaller meetings in which members of a clan, a patriline, or family gather to further discuss the issues raised in the earlier meeting. The community or community leaders meet again and so on. This round of discussions can continue for months.

The basic discursive activity of Yopno discussions consists of participants offering up their suggestions and concerns about community issues, and commenting on the suggestions and concerns of others. In the following example drawn from the same discussion introduced previously (see example (1)), leaders in Nian village are developing a strategy to elicit pigs from community members for an upcoming church celebration. After some discussion, the community's church worker (known as an evangelist) suggests that they buy some pigs with the church's money. The following is extracted from a discussion that ran for over an hour.

(10) Evangelist: Something [i.e. the pigs] given [to the church] for an offering, you [community members] have taken as your own. There are none 
that are ready now [i.e. big enough to be used]. You see some big ones, let's use those. Whatever we see, get them and let's do it, let's use them.

Another possibility is those congregants who don't feel able [to give a pig], they can get together and gather money and we buy another. Tomorrow [at a meeting of the wider community], let's speak out about all of this.

[This is followed by another man's speech, omitted here]

Tim: O Chairman! You can't go right to the option of money, forget it. We must gather the congregation and let them speak out from their heart [i.e. about what they are willing to do to provide pigs]. We can go with the money option but if we talk right away about money then the Congregation will go stand apart from us and say: "you yourselves do it with money!" Forget about the money option and inspire the Congregation. Afterwards, you'll see them bring what they've taken that belongs to the community and after that you can go with the money option. You go with money, you prevent them from returning pigs. They'll say: "They will do something for me with money" and will take the pig that belongs to the community and put it in their area.

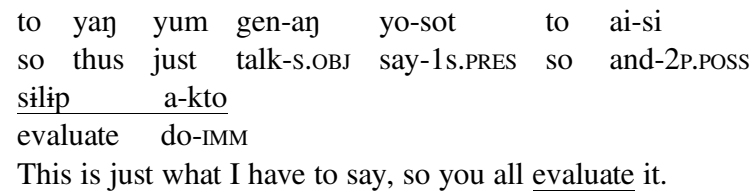

Throughout his speech, Tim does a couple of things that characterize discussion in meetings: he verbally 'evaluates' the talk of the evangelist and he offers up his own suggestions which, as he says, are to be 'evaluated' by others in turn.

Discussion, then, is composed of a great deal of talk about talk; communication itself is the crux of this ritual. It is common at the beginning of a turn at talk in discussion to explicitly link one's contribution to earlier talk, emphasizing that one is performing a variety of actions on another's talk.

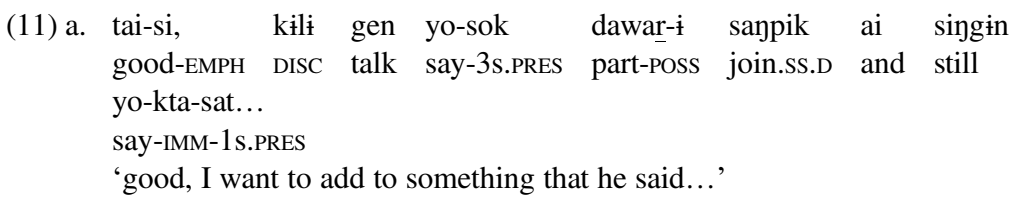
b. gen kila, on gen-tim-jok abisok-gok yo-sol un... talk leader this talk-portion-DIMIN now-DIMIN say-2s.PRES that 'Chairman, this thing you say just now, it's...'



c. money un yip dakwon amin ya-y un money that put.NOM GEN thing say-2/3P.NPAST that 'what you have said about putting money, it's...'

Following these opening phrases, participants 'break up', 'evaluate', 'add to', 'strengthen', and otherwise work over the talk that has preceded their own. In other words, they play the role of agentive recipients of others' talk in a verbal and public way. The 'active reception of other speakers' speech' (Vološinov 1986:117) is made palpable as an agentive activity in the very practice of talk.

In asserting themselves as agentive actors in this communicative ritual, participants assert their self-determination and equality, their capacity to work on the talk of others and not simply be passive recipients of another's dictates. Discussion continues as long as participants have more to say. If agreement cannot be reached, the discussion is taken up again at a later time or simply dropped. It concludes when, after much examination, a plan of action is collectively approved by participants, who respond $o$ 'yes' when asked if they are 'of one mind' or 'of one will' (but esal $a$-). In effect, this agreed-upon course of action is the collective 'talk' (gen) of all of those at the meeting. From self-determining participants each speaking and evaluating the speech of others emerges a consensus, a common word and a common will. ${ }^{13}$

At the same time as participants display their self-determination and equality by agentively receiving, evaluating, and holding onto others' talk, they display their respect for others' self-determination and equality in offering up suggestions for others to evaluate and discuss. The point is brought home in a standard formula used to wrap up a turn of talk in these meetings (for another example, see the last line of Tim's speech in (10)).

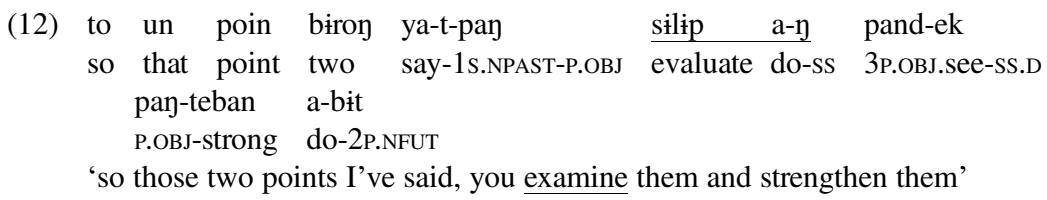

The formula, which includes the fashion of speaking involving silip a- ('group, sort out, distribute, evaluate'; see the discussion around (7)), describes the activity that is going on here: the sender is 'offering up' talk and recipients are publicly 'evaluating it'. The fashion of speaking is an explicit metadiscursive representation of discussion, which manifests implicitly in interactional practice the agentive recipient depicted in the fashion of speaking. Not only does this metadiscursive characterization represent what is going on in discussion, it is also a constitutive part of this communicative ritual: through the use of the fashion of speaking (with first and second person subjects), participants recognize the agency of those receiving their talk and their status as self-determining participants in village affairs. 
Discussion is a communicative practice in which people work to constitute the Yopno village as a polity composed of self-determining equals sharing a collective will. In the way people communicate with each other and the way they talk about how they communicate with each other, discussion forms a microcosmic realization in the medium of talk of a more general ideal of political relations; in talking about each others' talk, people act as self-determining agents with respect to others and display their equality and respect for others' self-determination. Moreover, as a mode of talk that ideally leads to the concerted action of a community, discussion provides a conspicuous model of talk as a perlocutionary act: between talk and the collective efforts of the community lies the agentive reception of talk by other community members.

This communicative practice extends out from any particular discussion to encompass other members of the community through the circulation of talk across multiple events of discussion. After community leaders have discussed a matter and have reached a consensus, that collective word then circulates to other members of the community for them to discuss, evaluate, and make suggestions of their own. After telling community members of the consensus reached by the village's leading men, one leader put it this way.

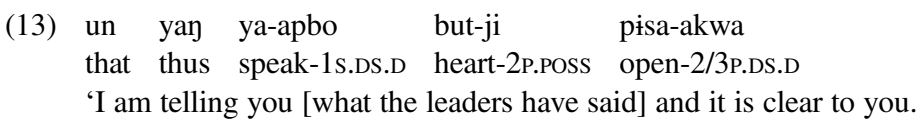

$\begin{array}{lllllll}\text { kili } & \text { u-donda } & \text { disi } & \text { nand-ek } & \text { gen } & \text { di } & \text { yo-ni } \\ \text { DISC } & \text { that-ABL } & \text { 2P.EMPH } & \text { hear/think-SS.D talk } & \text { some } & \text { speak-2/3P.FUT }\end{array}$

You think this over and talk about it.

kili tek un yipmay-kaman kan-ba tai a-sak bo nian

DISC neck that put-1P.PRES 3s.OBJ.see-2/3P.DS good do-3s.PRES or like.what The talk we [leaders] are putting forward, you see if it is good or not.

un un kili disi gen silip ek yo-n

that that DISC 2P.EMPH talk evaluate do.SS.D speak-2/3P.PRES

You all evaluate it and talk.'

The leading men of the community formulate a plan through discussion, bring it to the community for further discussion, after which the leaders may meet again to revise the talk, perhaps each holds meetings with their own clan, and so on and so forth. Through the round of discussions, participants work to constitute a polity of equal, self-determining persons that encompasses the entire community, or at least its adult men.

Even as this political practice emphasizes the equality and self-determination of participants, there is a marked inequality in the way talk circulates. The leading men of the community go first - they work over the 'talk' first, taking a leading role in evaluating it. There are other inequalities too-the general lack of female 
participation is notable - and we may certainly question whether all involved are equally self-determining even when they do participate. The description of discussion I have offered here highlights political sensibilities that inform the practice of discussion, even as discussions often fall short of meeting them. Indeed, even after round and round of discussion, many people will remain dissatisfied and aloof from community affairs. People simply avoid meetings if they feel excluded, chastised, or pressed to do things they would rather not. In the discussion concerning pigs for the church celebration in Nian, leading men of one lineage were notably absent, an absence chalked up to their fear that discussion would turn to the pigs that they had borrowed from the congregation and that they had not repaid.

Where discussion is a mode of forging a polity of self-determining men through mutual respect for and exercise of communicative agency, the recurring failure of discussion and the speeches of leaders to result in collective action is a constant reminder of the dark side of self-determination. Talk about such failures presents them as resulting from villagers' willfulness, which is regarded both as a threat to the community and its projects and as an attribute fundamental to villagers' nature. People are said to follow their desires (but yol-) instead of following talk (gen yol-), identifying willfulness as a problem of talk and its reception. Leaders and community members alike harangue those who do not heed instructions, employing fashions of speaking that emphasize the act of reception and the work of recipients, the weak link standing between talk and the success of collective endeavors. Example (4), for instance, was uttered by a woman as a small group sat around waiting in vain for community members to show up for a meeting to plan some construction work on the local school. She criticizes community members for their failure to receive speech in the proper way, to keep in mind the instructions of the teachers, who had long ago requested that this work be done. In using a fashion of speaking that emphasizes recipient agency, she presents the perlocutionary outcome - the failure to do the construction work on the school—as the product of the recipients' agentive (mis)handling of the teachers' instructions.

Not only the exemplary back and forth of discussion, then, but recurring failures of collective action featured in harangues are a constant reminder of the critical role of recipients in determining the outcome of speech events. The important role of recipients is also evident in the strategic efforts of speakers to tune their speech carefully to their recipients (see example (1)) in order to secure their support for a desired course of action. Leaders encourage recipients to exercise their agency in particular ways, peppering their speeches with directives about how the audience should receive speech.

\footnotetext{
(14) gen u-nay kokwin-ek abido-sol talk that-S.OBJ examine-ss.D hold-2s.PRES 'Think about that talk and hold onto it'
}

The attention speakers give to the reception of their speech indicates again the critical role recipients are seen to play in shaping the outcome of speech events in a 
political environment in which people are regarded as willful, self-determining actors.

In relatively acephalous Yopno villages, where residents value their self-determination and have the means to exercise it, the recipient and their agency are a focal point of attention. The recurring failure of villagers to heed talk and the ever-present possibility of such failure spotlights the role of the recipient, the willful, self-determining fulcrum lying between speech and its outcome. Those who would lead the community strategize about ways of speaking that will elicit their addressees' willing involvement in collective activities. And in discussion, participants work to forge a common will through the verbal and public 'reception' of one another's speech.

In all of these ways, village politics, with its emphasis on villagers' willfulness and self-determination, fosters a conception of perlocutions in which agentive recipients play a prime role in shaping the outcome of speech events. Discussion puts on display the long process of examining, adding to, strengthening, and otherwise working over the talk of others through which self-determining participants align their wills. Here is the perlocutionary writ large, in a highly visible, public ritual that is centered on speech itself and the work of recipients, whose evaluation of others' speech stands between talk and collective action. And when talk fails to produce a desired outcome, this failure is often presented as a failure of reception, once again highlighting the role of the willful, self-determining recipient as a mediator between speech and its outcome. Mingling politics and perlocutionary models, discussion, harangues, and the oratory of community leaders are key sites where a political sensibility that recognizes and even values villagers' selfdetermination is knit together with a model of perlocutions - a model in which the communicative recipient is the fulcrum lying between speech and collective action.

\author{
CONCLUSION: THE POLITICA L IS \\ P E R L O C U T I O N A R Y
}

I have sought to detail here a recipient-centered model of linguistic efficacy embodied in the ritual practice of discussion as well as in a set of Yopno fashions of speaking about speech. As discursive embodiments of language ideologies, these fashions of speaking are 'sited' in social contexts of use - in institutions, rituals, and activities where they are prominent and routine - and they are shaped by nonlinguistic concerns that animate these activities. Here I have shown how a model that emphasizes the role of recipients in shaping the outcome of speech events is molded by a political ethos that stresses self-determination and equality, and political practices through which participants work to constitute the Yopno village as a polity composed of self-determining men. In this respect, the perlocutionary is political; political sensibilities and practices form a prism through which the causal nexus of speech and its outcome is apprehended. 
But viewed another way, the political is perlocutionary. The relatively acephalous political organization of Yopno villages is reinforced by conceptions and practices that stress the agentive role of recipients in swaying the outcome of communicative events. A would-be leader's word is nobody's command; the success of efforts to direct community members is understood to be contingent on the way directions are 'handled' by their recipients. Speakers frame their contributions with an eye toward their addresses' uptake, submitting their speech to the receptive activity of others. While some may have the verbal skill to reliably stir their addresses to act, their influence remains precarious - they exercise verbal power at the pleasure of the communicative recipient.

In closing, it is worth considering briefly how perlocutionary conceptions shed light on the kinds of speech - the verbal 'techniques of power' - sanctioned and used in political discourse. Political oratory has long been a prime domain in which scholars and other commentators have approached speech as a mode of consequential action, '[a]s speech to a listening collectivity that is understood to have potentially powerful consequences by dint of the speech's own qualities' (Stasch 2011:160). How then do cultural understandings of the causal nexus of speech and its effects shape the kinds of speech deemed potent in political oratory?

Looking back to example (1), we can see the interplay of perlocutionary model and political oratory at work. In this example, the speaker situates the speech he would present to community members ('giving pigs is a way to secure blessings') in relation to the 'evaluation' of that speech by the prospective recipient and the outcome of that evaluation. What the speaker presents to this prospective recipient is a representation of the nature of reality - what Searle terms a 'representative' speech act (1976) - which is keyed to a recipient who is expected to evaluate speech for themselves, determining whether it is true or false, good or bad. In crafting 'persuasive' oratory in strategy sessions such as this one, speakers anticipate the activity of recipients 'breaking up', 'evaluating', and 'holding onto' speech and shape their speech accordingly. And indeed, much political discourse in the Yopno Valley takes the form of representative statements (Slotta 2014), which are oriented to the particular sorts of agentive actions that recipients are understood and expected to perform on such speech. In a political environment in which actors are presumed to be willful and self-determining, representations of reality and how to act effectively in it are presented in an effort to channel others' willfulness. In instructing others in the nature and workings of the world, knowledgeable authorities such as the church leader in (1) offer up knowledge that may inform others' decision-making and influence their actions, if they listen and accept it.

Different perlocutionary sensibilities motivate different verbal techniques of power. Deliberative democratic models of public sphere discourse, for instance, privilege argumentation, not instruction, as a particularly legitimate and effective means of influence (Benhabib 1994). The legitimacy and effectiveness of argumentation is grounded in a perlocutionary conception in which rational judgment, seen as a fundamental human capacity shared equally by almost all, mediates between speech and its 
outcome. In argumentation, in the words of Habermas, '[t]he taking of yes/no positions is motivated solely by the unforced force of the better argument' (1996:306). Recalling Kant's unease with rhetoric as a mode of exerting influence that robs listeners of their freedom, contemporary discussions of deliberative democracy put forward argumentation and deliberation as particularly legitimate forms of verbal power that uphold the freedom of listeners by allowing them autonomous use of their rational judgment (Garsten 2011). While the focus on argumentation in deliberative democratic theory has been much criticized, both for its exclusion of other modes of discourse and its lack of correspondence to the practice of politics in 'actually existing democracy' (Fraser 1990), it is motivated by a liberal perlocutionary sensibility that views reason as the legitimate arbiter of speech, as a human capacity that should determine the outcome of speech events. Modes of exerting influence, the techniques of power routinized and sanctioned in a polity, then, take shape in relation to varied conceptions of the causal nexus of speech and its outcome, and their legitimacy.

The linguistic and ethnographic investigation of fashions of speaking, political rituals, and verbal techniques of power I have presented here points up a dialectic in which political sensibilities and practices shape cultural models of perlocutions and such models give shape to politics, political oratory, and conceptions of power. As Tambiah (1977: 91) says in a different context, 'the cultural model and the pragmatic parameters are in concordance and buttress one another'. That is, of course, not to say that there is a single cultural model of perlocutions or a single set of shared political values and practices operative in Yopno villages. Nor is it to say that practices and ideologies, perlocutions and politics never come into conflict with each other, though that has not been my focus here. Rather, the intertwining of the perlocutionary and the political points up the way in which practice bears on ideology and ideology on practice in particular sites - fashions of speaking, political rituals, styles of oratory - where the one molds the other, where political practices and cultural models of perlocutions, political sensibilities and linguistic practices have 'grown up together, constantly influencing each other'.

\section{N O T E S}

*I must thank all of the people in the Yopno Valley who supported this research in one way or another. An early draft of this article was presented at the Linguistic Anthropology Workshop at the University of California, San Diego. I thank Kit Woolard, John Haviland, Rupert Stasch, and others there for their valuable comments and suggestions. Luke Fleming and Courtney Handman read a number of drafts and provided suggestions that improved the article significantly. I gratefully acknowledge funding for this research provided by the Fulbright-Hayes Program, the Wenner-Gren Foundation, and the Endangered Languages Documentation Programme. Finally, I'd like to thank Jenny Cheshire and two anonymous reviewers for 'breaking up' and 'evaluating' this article with great care.

${ }^{1}$ In Lectures 9 and 10, Austin grapples with the distinction between the illocutionary and the perlocutionary facets of speech acts. While perlocutionary acts concern speech as an activity that gives rise to effects, illocutionary acts as conventional varieties of social action seem also to give rise to effects- for example, when someone meeting all of the felicity conditions says "I christen this ship the Karl Marx", a consequence of the illocutionary act of 'christening' is that the ship is thus named. It proves difficult to distinguish perlocutionary effects from such seemingly automatic consequences of 


\section{JAMES SLOTTA}

illocutionary acts. Austin and others have put forward various characteristics that distinguish illocutionary and perlocutionary acts: illocutionary acts depend on conventions, speaker intentions, forces that are conveyed in speech, and so on in a way that perlocutionary acts do not. Others have argued that illocutionary acts are a special type of perlocution (Sadock 1974:152-54).

As I discuss in a later section, Austin's dissection of speech acts into the locutionary, illocutionary, and perlocutionary builds off of a variety of words and expressions in English that describe speech events in different ways (Silverstein 1979). There is no reason to expect, then, that Austin's analysis will be internally coherent. I use the term perlocution here to indicate the relationship of speech to outcomes that are said to follow from it, whether this connection between speech and outcome is seen as automatic or contingent on various mediations. I do not mean to suggest that the trinity locutionary, illocutionary, perlocutionary form an adequate description of speech acts. The term perlocutionary is useful here insofar as it is familiar and it provides a one-word caption for speech regarded as a consequential activity.

${ }^{2}$ See Cohen (1973), Gaines (1979), Gu (1993), Kurzon (1998), and Marcu (2000) for discussion of perlocutions and problems the perlocutionary poses to a number of philosophical and linguistic approaches to pragmatics.

${ }^{3}$ This concern with rhetoric is part of a broader early modern epistemological concern with how sense impressions and signs give rise to knowledge and belief. Because sense impressions and signs can deceive, the mediation of an individual's rational judgment is deemed crucial to ensure that they are properly interpreted. In the words of John Locke, 'Careful reflection, thought, and attention by the mind is needed, in order that by argument and reasoning one may find a way from perceptible and obvious things into their hidden nature' (1997:95). The human capacity for rational judgment is an important component of an emerging scientific epistemology in early modern Europe. At the same time, it is an important element of an emerging liberal political ethics that sought to liberate individuals from traditional sources of authority that lie outside themselves by stressing the authority of an individual's rational judgment. Of course, rationality as a criterion of legitimate judgment introduced a new basis for legitimizing the stratification of polities along gender and class lines (Bauman \& Briggs 2000).

${ }^{4}$ See, for instance, Goodwin (1979), Duranti \& Brenneis (1986), Bavelas, Coates, \& Johnson (2000), as well as work on 'decoding' and 'active audiences' in the study of mass media and communication, for example, Hall (1980) and Fiske (1987:Ch. 5).

${ }^{5}$ Expressions used to describe the reception of speech are underlined in the transcript that follows, and in other examples in the article. The orthography used here was developed for the Yopno language by SIL Bible translators, and it has become relatively standard in Yopno communities. Most letters have roughly the same pronunciation as their IPA counterparts, but a few require additional comment.

i a middle-low vowel, roughly equivalent to schwa in English

$\mathrm{k}$ generally pronounced as an unvoiced postvelar stop

g generally pronounced as a voiced postvelar stop

y generally pronounced as a postvelar nasal

$\mathrm{j}$ a voiced postalveolar affricate, equivalent to the $j$ in English judge

$\mathrm{r}$ alveolar tap

Abbreviations of glosses are listed below.

\begin{tabular}{|c|c|c|c|}
\hline 1 & first person & LOC & locative enclitic \\
\hline 2 & second person & NFUT & near future tense/imperative \\
\hline 3 & third person & NOM & nominalizer \\
\hline $\mathrm{ABL}$ & ablative enclitic & NPAST & near past tense/perfect \\
\hline DAT & dative enclitic & OBJ & $\begin{array}{l}\text { object/instrumental enclitic with nouns or } \\
\text { object cross-referencing prefix on verbs }\end{array}$ \\
\hline DIMIN & diminutive & $\mathrm{P}$ & plural \\
\hline DISC & discourse marker & POSS & possessor cross-referencing suffix in head- \\
\hline DS & different subject serial & & marking possessive construction \\
\hline & verb inflection & PRES & present/unmarked tense \\
\hline
\end{tabular}




\section{THE PERLOCUTIONARY IS POLITICAL}

$\begin{array}{ll}\text { DS.D } & \text { different subject dependent verb } \\ & \text { inflection } \\ \text { EMPH } & \text { emphatic } \\ \text { FUT } & \text { future tense/irrealis } \\ \text { GEN } & \text { genitive enclitic } \\ \text { IMM } & \text { imminent/desiderative }\end{array}$

$\begin{array}{ll}\text { S } & \text { singular } \\ \text { SS } & \text { same subject serial verb inflection } \\ \text { SS.D } & \text { same subject dependent verb inflection } \\ \text { SUBJ } & \text { subject enclitic } \\ \text { TOP } & \text { topicalizer }\end{array}$

${ }^{6}$ For instance, locutionary and illocutionary verbs pattern for the most part with what Vendler (1957) termed 'activity verbs' whereas perlocutionary verbs as well as analytic and other lexical causative verbs pattern with 'accomplishment verbs'.
Activity verb
Locutionary verb
I stopped playing soccer after ten minutes.
Illocutionary verb
I stopped saying "Play soccer!" after ten minutes.
Perlocutionary verb
I stopped urging you to play soccer after ten minutes.
*I stopped convincing you to play soccer after ten minutes.
(Cf. I stopped trying to convince you to play soccer after ten minutes.)
Analytic causative
*I stopped getting you to play soccer after ten minutes.
(Cf. I stopped trying to get you to play soccer after ten minutes.)

Austin picks up on another distributional parallel in his discussion of the difference between illocutionary and perlocutionary acts (1962:121). Illocutionary verbs can occur with prepositional phrases indicating the locus or medium in which a speech act takes place. Perlocutionary verbs, as lexical causatives, generally do not:

Illocutionary verb In a compelling speech, he urged us to overthrow the government.

Perlocutionary verb *In a compelling speech, he persuaded us to overthrow the government.

Analytic causative *In a compelling speech, he got us to overthrow the government.

An adverb of means, by contrast, can be used with perlocutionary verbs and analytic causatives alike to indicate the means used to bring about an effect:

Illocutionary verb ?By means of a compelling speech, he urged me to come.

Perlocutionary verb By means of a compelling speech, he persuaded us to come.

Analytic causative By means of a compelling speech, he got me to come.

${ }^{7}$ The English verb persuade has played an important role in the scholarly metalanguage used to describe Melanesian leadership (Chowning 1979; Watson-Gegeo 1986). While use of the term is certainly warranted, closer consideration of perlocutionary metalanguages in use in Melanesian speech communities can provide guidance in refining our understanding of leadership and language use in Melanesia. Given the grammatical and semantic particularities of the English verb persuade and the connotations accrued by it as one of the prime terms of art in the European rhetorical tradition, the term carries a great deal of baggage that must be carefully unpacked.

${ }^{8}$ In serial verb constructions, one verb or verb phrase serves as the complement or adjunct of another. For instance, the verb of speaking, ya-, may be combined with the verb sinsina- 'to be visible, to be alight' in a serial verb construction to form an expression with a more specific meaning:

(i) ya- $n \quad$ sinsino-sot speak-ss be.visible-1s.PRES

'I speak openly, I speak out'

For more details on serial verb constructions in Papuan languages see Foley (1986) and for a broader typological overview see Aikhenvald (2006). Further semantic specification can also be achieved through modification of the noun of speaking gen (e.g. bukmi gen 'apology', lit. 'sorry talk', nuwa gen 'command, order', lit. 'law talk'). There are a few other verbs related to speaking, including the (di)transitive - $i$ - 'to say to, tell, call' and manji- 'to read, to count'. With most speakers of Yopno now 
bilingual in Tok Pisin, a number of metalinguistic nouns from English and Tok Pisin have been borrowed (e.g. oda 'order', edvaisi 'advice', poin 'point [of what someone says]').

${ }^{9}$ Though I noted above that gen can be used to denote the 'soundings' of various animate and inanimate subjects, in combination with the verbs discussed in the remainder of this section gen can only be construed as 'human speech'; animals, bells, thunder, and the like are not possible producers of this gen. For this reason, I speak of gen in the remainder of this section as a noun of speaking, though in other linguistic contexts it has a more generic meaning.

${ }^{10}$ Additionally, all of the fashions of speaking discussed in this section combine with purpose clauses, another indication that their subject argument is characterized as volitional, controlling, and instigating: nandak nandak pakto geni kokwinat 'I thought over his talk to gain some understanding'. Constructions like this one have been elicited and judged acceptable, though I have no examples of their use apart from elicitation.

${ }^{11}$ There are, for instance, ways of talking about speech and its effects in Yopno that resemble the perlocutionary expressions considered by Austin:

(i) nin y-ek but-ni a-wo-no

1P speak-ss.D heart-3.POSS S.OBJ-go.up-1P.NFUT

'We must speak and make his heart go up (i.e. We must inspire him)'

Here, the act of speech is joined with a Yopno causative construction $a$-wo 'cause to go up', formed from a verb of motion and a valence-increasing prefix. The Yopno expression combines speech and causation in much the same way English lexical causative verbs like persuade do. Interestingly, the direct object in the Yopno expression is often the affected person's but 'insides, heart, will', which is commonly the subject of predicates of emotion.

It should be noted that much Whorf-inspired research has focused on fashions of speaking that involve what Whorf termed 'selective' grammatical categories (Whorf 1956:93-95), categories that partition lexical forms in a language into mutually exclusive classes, such as count and mass nouns in English (see Lucy (1992) for an exemplary study). Semantic properties of a selective category are part of the meaning of lexical forms that are members of that category; they are 'in the lexeme', as Whorf says. For instance, part of the meaning of the word sand derives from its classification as a mass noun, a selective category of English grammar.

In contrast, the fashions of speaking I discuss here involve semantic properties that are akin to Whorf's 'modulus' grammatical categories, categories 'generally applicable and removable at will' (Whorf 1956:95). Through the collocation of nouns and verbs of speaking with verbs like 'break up', 'sort', and 'hold onto', the reception of talk is characterized as an activity in which the communicative recipient agentively handles talk in various ways. This way of characterizing talk is 'applicable and removable at will', that is, this characterization of talk is not grammatically obligatorily or 'in the lexeme', but results from the optional collocation of various elements. In cases where fashions of speaking involve grammatical and semantic properties that are modulus in character, it is not so much a grammar that can be said to classify lexical forms in certain ways (as is the case with selective categories); rather it is the use in discourse of possibilities afforded by a grammar that serves to characterize lexical forms in certain ways. Because modulus categories are optional, it is necessary to attend closely to their use in discourse. In addition, there may be alternative modulus categories that can be and are applied to the same lexical forms, giving rise to different characterizations of the same form. There are Yopno fashions of speaking in which talk is something agentively handled by the recipient; but talk may also be described, as in the example above, as something that affects the recipient, that causes them to feel or do something. It is imperative then to attend closely not only to routine fashions of speaking found in discourse, but to the social 'distribution' of alternative ways of putting things.

${ }^{12}$ Ethnographies of Melanesia have reported a number of ways in which discursive practice is keyed to the role recipients are seen to play in interaction (Kulick 1992; Rodman 1991; Silverstein 1998; Schieffelin 2008; Stasch 2008). Schieffelin, for instance, reports that among Bosavi 'appeals for co-operation must be phrased so that the participants can appear to have chosen to take part of their own free will' (1976:129; see also Schieffelin 1990; Kulick 1992). Brenneis notes that the

Language in Society 44:4 (2015) 
indirectness characteristic of talanoa in a rural Fiji Indian community 'leaves open the options of one's listeners. The possibility of multiple interpretation helps to maintain the autonomy of participants: they are not forced to accept a straightforward and unambiguous account' (1984:496). Though I focus on discussion in this article, a number of practices discussed in this literature are part of the repertoire of Yopno communicative practices. I focus on discussion here because it is a highly visible public ritual in which much of the community participates on a regular basis and, moreover, it is one that directs attention to the act of communication itself. As such, it is a particularly prominent site where the agency of recipients is foregrounded in Yopno communicative practice.

${ }^{13}$ Of course, publically voiced consensus may mask underlying dissensus. If people do not express their views in discussion or feel that their contributions have not been properly heard, they exercise their self-determination by not participating in the agreed upon course of action. This is the antisocial side of self-determination that I discuss later in this section, one that has the potential to drive further discussion if enough people fail to join in collective endeavors.

As in many small-scale polities comprised of egalitarian-minded members who jealously guard their autonomy, politics can appear to be 'all talk and no action'. Don Kulick's description of oratory in a Papua New Guinean village is largely applicable to Yopno discussions as well:

In oratory, stress is not placed on solving problems or actually achieving concrete results, although this is one potential outcome of the meetings in the men's house, and it is occasionally realized. More often, however, when the time comes to perform the activity that had been agreed upon, the consensus that had been arrived at in the men's house during oratorical speeches is ignored by some or even most of the individuals who had been present and took part in making the decision in the first place. (Kulick 1992:126)

But in these kinds of polities, endless meetings, and efforts to achieve consensus are often themselves the embodiment of the polity (Myers \& Brenneis 1984; Myers 1986). Yopno discussions are particularly interesting for the emphasis they place on agentive reception as a mode in which participants display their self-determination in the course of formulating a collective word and a collective will.

\section{R E F E R E N C E S}

Aikhenvald, Alexandra Y. (2006). Serial verb constructions in typological perspective. In Alexandra Y. Aikhenvald \& R. M. W. Dixon (eds.), Serial verb constructions: A cross-linguistic typology, 1-68. Oxford: Oxford University Press.

Austin, J. L. (1962). How to do things with words: The William James lectures delivered at Harvard University in 1955. Oxford: Oxford University Press.

Bauman, Richard, \& Charles L. Briggs (2000). Language philosophy as language ideology: John Locke and Johann Gottfried Herder. In Paul V. Kroskrity (ed.), Regimes of language: Ideologies, polities, and identities, 139-204. Santa Fe, NM: School of American Research Press.

Bavelas, Janet B.; Linda Coates; \& Trudy Johnson (2000). Listeners as co-narrators. Journal of Personality and Social Psychology 79:941-52.

Benhabib, Seyla (1994). Deliberative rationality and models of democratic legitimacy. Constellations $1(1): 26-52$.

Brenneis, Donald (1984). Grog and gossip in Bhatgaon: Style and substance in Fiji Indian conversation. American Ethnologist 11:487-506.

(1987). Performing passions: Aesthetics and politics in an occasionally egalitarian community. American Ethnologist 14:236-50.

Briggs, Charles L. (1992). Linguistic ideologies and the naturalization of power in Warao discourse. Pragmatics 2:387-404.

Language in Society 44:4 (2015) 


\section{JAMES SLOTTA}

Chowning, Ann (1979). Leadership in Melanesia. The Journal of Pacific History 14:66-84.

Cohen, Ted (1973). Illocutions and perlocutions. Foundations of Language 9:492-503.

Duranti, Alessandro (1992). Intentions, self, and responsibility: An essay in Samoan ethnopragmatics. In Jane H. Hill \& Judith T. Irvine (eds.), Responsibility and evidence in oral discourse, 24-47. Cambridge: Cambridge University Press.

Duranti, Alessandro, \& Donald Brenneis (eds.) (1986). Special issue on 'The audience as co-author'. Text 6(3).

Fiske, John (1987). Television culture. New York: Methuen \& Co.

Foley, William A. (1986). The Papuan languages of New Guinea. Cambridge: Cambridge University Press.

Fontana, Benedetto; Cary J. Nederman; \& Gary Remer (eds.) (2004). Talking democracy: Historical perspectives on rhetoric and democracy. University Park: The Pennsylvania State University Press.

Fraser, Nancy (1990). Rethinking the public sphere: A contribution to the critique of actually existing democracy. Social Text 25/26:56-80.

Gaines, Robert N. (1979). Doing by saying: Toward a theory of perlocution. The Quarterly Journal of Speech 65:207-17.

Garsten, Bryan (2009). Saving persuasion: A defense of rhetoric and judgment. Cambridge, MA: Harvard University Press.

- (2011). The rhetoric revival in political theory. Annual Review of Political Science 14:159-80.

Goldman, Laurence (1983). Talk never dies: The language of Huli disputes. London: Tavistock.

Goodwin, Charles (1979). The interactive construction of a sentence in natural conversation. In George Psathas (ed.), Everyday language: Studies in ethnomethodology, 97-121. New York: Irvington Publishers.

Gu, Yueguo (1993). The impasse of perlocution. Journal of Pragmatics 20(5):405-32.

Gustafson, Thomas (1992). Representative words: Politics, literature, and the American language, 1776-1865. Cambridge: Cambridge University Press.

Habermas, Jurgen (1996). Between facts and norms: Contributions to a discourse theory of law and democracy. Cambridge, MA: MIT Press.

Hall, Stuart (1980). Encoding/decoding. In Stuart Hall, Dorothy Hobson, Andrew Lowe, \& Paul Willis (eds.), Culture, media, language: Working papers in cultural studies, 1972-79, 117-27. New York: Routledge.

Handman, Courtney (2015). Critical Christianity: Translation and denominational conflict in Papua New Guinea. Berkeley: University of California Press.

Hirschkind, Charles (2006). The ethical soundscape: Cassette sermons and Islamic counterpublics. New York: Columbia University Press.

Kant, Immanuel (2000). Critique of the power of judgment, ed. by Paul Guyer. New York: Cambridge University Press.

Kapchan, Deborah A. (2008). The promise of sonic translation: Performing the festive sacred in Morocco. American Anthropologist 110:467-83.

Katz, Jerrold J. (1977). Propositional structure and illocutionary force: A study of the contribution of sentence meaning to speech acts. Cambridge, MA: Harvard University Press.

Kennedy, George A. (2006). Aristotle, on rhetoric: A theory of civic discourse. New York: Oxford University Press.

Konstan, David (2006). The emotions of the ancient Greeks: Studies in Aristotle and classical literature. Toronto: University of Toronto Press.

Kroskrity, Paul V. (1998). Arizona Tewa Kiva speech as a manifestation of a dominant language ideology. In Bambi B. Schieffelin, Kathryn A. Woolard, \& Paul V. Kroskrity (eds.), Language ideologies: Practice and theory, 103-22. Oxford: Oxford University Press.

(2000a). Regimenting languages: Language ideological perspectives. In Paul V. Kroskrity (ed.), Regimes of language: Ideologies, polities, and identities, 1-34. Santa Fe, NM: School of American Research Press. 


\section{THE PERLOCUTIONARY IS POLITICAL}

(2000b). Regimes of language: Ideologies, polities, and identities. Santa Fe, NM: School of American Research Press.

Kulick, Don (1992). Language shift and cultural reproduction: Socialization, self and syncretism in a Papua New Guinean village. Cambridge: Cambridge University Press.

Kurzon, Dennis (1998). The speech act status of incitement: Perlocutionary acts revisited. Journal of Pragmatics 29:571-96.

Locke, John (1997). Locke: Political essays, ed. by Mark Goldie. Cambridge: Cambridge University Press.

Lucy, John A. (1992). Grammatical categories and cognition: A case study of the linguistic relativity hypothesis. Cambridge: Cambridge University Press.

Marcu, Daniel (2000). Perlocutions: The Achilles' heel of speech act theory. Journal of Pragmatics 32:1719-41.

Marsilli-Vargas, Xochitl (2014). Listening genres: The emergence of relevance structures through the reception of sound. Journal of Pragmatics 69:42-51.

Merlan, Francesca, \& Alan Rumsey (1991). Ku Waru: Language and segmentary politics in the Western Nebilyer Valley, Papua New Guinea. Cambridge: Cambridge University Press.

Myers, Fred R. (1986). Reflections on a meeting: Structure, language, and the polity in a small-scale society. American Ethnologist 13:430-47.

— \& Donald Lawrence Brenneis (1984). Introduction: Language and politics in the Pacific. In Donald Lawrence Brenneis \& Fred R. Myers (eds.), Dangerous words: Language and politics in the Pacific, 1-29. New York: New York University Press.

Pawley, Andrew (1993). A language which defies description by ordinary means. In William A. Foley (ed.), The role of theory in language description, 87-129. Berlin: Mouton de Gruyter.

(1994). Kalam exponents of lexical and semantic primitives. In Goddard Cliff \& Anna Wierzbicka (eds.), Semantic and lexical universals: Theory and empirical findings, 387421. Amsterdam: John Benjamins.

Philips, Susan Urmston (1976). Some sources of cultural variability in the regulation of talk. Language in Society 5(1):81-95.

(2000). Constructing a Tongan nation-state through language ideology in the courtroom. In Paul V. Kroskrity (ed.), Regimes of language: Ideologies, polities, and identities, 229-57. Santa Fe, NM: School of American Research Press.

Read, K. E. (1959). Leadership and consensus in a New Guinea society. American Anthropologist 61:425-36.

Robbins, Joel (2001). God is nothing but talk: Modernity, language, and prayer in a Papua New Guinea society. American Anthropologist 103:901-12.

Rodman, William L. (1991). When questions are answers: The message of anthropology, according to the people of Ambae. American Anthropologist 93:421-34.

Rosaldo, Michelle Z. (1982). The things we do with words: Ilongot speech acts and speech act theory in philosophy. Language in Society 11:203-37.

Sadock, Jerrold M. (1974). Toward a linguistic theory of speech acts. New York: Academic Press.

Schieffelin, Bambi B. (1990). The give and take of everyday life: Language socialization of Kaluli children. Cambridge: Cambridge University Press.

(2008). Speaking only your own mind: Reflections on talk, gossip and intentionality in Bosavi (PNG). Anthropological Quarterly 81:431-41.

— Kathryn A. Woolard; \& Paul V. Kroskrity (1998). Language ideologies: Practice and theory. Oxford: Oxford University Press.

Schieffelin, Edward L. (1976). The sorrow of the lonely and the burning of the dancers. New York: St. Martin's Press.

Searle, John R. (1969). Speech acts: An essay in the philosophy of language. Cambridge: Cambridge University Press.

(1976). A classification of illocutionary acts. Language in Society 5(1):1-23.

Language in Society 44:4 (2015) 


\section{JAMES SLOTTA}

Shapin, Steven (1996). The scientific revolution. Chicago: University of Chicago Press.

Shuger, Debora K. (1988). Sacred rhetoric: The Christian grand style in the English renaissance. Princeton, NJ: Princeton University Press.

Silverstein, Michael (1979). Language structure and linguistic ideology. In Paul R. Clyne, William F. Hanks, \& Carol L. Hofbauer (eds.), The elements: A parasession on linguistic units and levels, 193-247. Chicago: Chicago Linguistic Society.

(1998). The uses and utility of ideology: A commentary. In Bambi B. Schieffelin, Kathryn A. Woolard, \& Paul V. Kroskrity (eds.), Language ideologies: Practice and theory, 123-45. Oxford: Oxford University Press.

Skinner, Quentin (1996). Reason and rhetoric in the philosophy of Hobbes. Cambridge: Cambridge University Press.

Slotta, James (2014). Revelations of the world: Transnationalism and the politics of perception in Papua New Guinea. American Anthropologist 116:626-42.

Stasch, Rupert (2008). Knowing minds is a matter of authority: Political dimensions of opacity statements in Korowai moral psychology. Anthropological Quarterly 81:443-53.

(2009). Society of others: Kinship and mourning in a West Papuan place. Berkeley: University of California Press.

(2011). Ritual and oratory revisited: The semiotics of effective action. Annual Review of Anthropology 40:159-74.

Tambiah, Stanley J. (1977). The galactic polity: The structure of traditional kingdoms in Southeast Asia. Annals of the New York Academy of Sciences 293:69-97.

Van Valin, Jr., Robert D. (2005). Exploring the syntax-semantics interface. Cambridge: Cambridge University Press.

Vendler, Zeno (1957). Verbs and times. The Philosophical Review 66:143-60.

Vološinov, V. N. (1986). Marxism and the philosophy of language. Cambridge, MA: Harvard University Press.

Wassmann, Jürg (1993). Worlds in mind: The experience of an outside world in a community of the Finisterre Range of Papua New Guinea. Oceania 64:117-45.

(1994). The Yupno as post-Newtonian scientists: The question of what is 'natural' in spatial description. Man, New Series 29:645-66.

Watson-Gegeo, K. A. (1986). The study of language use in Oceania. Annual Review of Anthropology 15:149-62.

Whorf, Benjamin Lee (1956). Language, thought and reality: Selected writings of Benjamin Lee Whorf, ed. by John B. Carroll. Cambridge, MA: MIT Press.

(Received 2 September 2014; revision received 11 February 2015; accepted 10 March 2015; final revision received 15 March 2015) 